\title{
The Usage of Cohesive Devices During Text Translation from Albanian to English and Vice
} Versa

\author{
Elsa Vula \\ Teaching assistant of English Linguistics, University of Gjakova "Fehmi Agani", Faculty of Philology
}

\begin{abstract}
Translation as a complicated process requires a great commitment and hard work in order to realize the text transformation in the best coherent and meaningful way. It is generally known, that no two languages in world have more similarities than differences in their construction. Because of high number of differences that they may share, problems or challenges in the process of translation increase. This research paper focuses on the usage of cohesive devices during text translation from Albanian to English and vice versa. Firstly, this paper introduces the theoretical background on translation, text linguistics and the internal part of a text. Secondly, it elaborates the importance of cohesion and coherence, as criteria of text linguistics as well as their role in the process of translation. In this research has been used the empirical method, in analyzing the texts translation from Albanian to English, by elaborating the addition of cohesive devices which enabled a coherent translation. In addition, there is presented a text translation from English to Albanian, which shows the non-coherent translation and coherent because of the differences among Albanian and English due to linguistic relativism, demonstrative pronouns and noun's cases.
\end{abstract}

Keywords: text translation, text linguistics, cohesion, coherence.

\section{Introduction}

Translation it is considered one of the most important tools in giving opportunity to: readers, listeners, viewers to read, listen and watch different; books, music, films in different languages which are realized through the process of translation.

What is translation?

"The English term translation, first attested in around 1340', derives either from Old French translation or more directly from the Latin translatio ('transporting), itself coming from the participle of the verb transferre (to carry over)" (Munday, 2016:8)

"In English we use the term "translation" to refer to the total process and relationship of equivalence between two languages: we then distinguish, within translation, between "translating" (written text) and "interpreting" (spoken text). So I will use the term "translation" to cover both written and spoken equivalence; and whether the equivalence is conceived of as process or as relationship" (Halliday, 1992:15).

"Translation is the production of a functional target text maintaining a relationship with a given source text that is specified according to the intended or demanding function of the target text (translation skopos)" (Nord,1991:28).

The issue for translators stands to find ways in order to gain a successful translation to the readers or audience. What is a successful translation?

A successful translation is when a transformed text or titles of film in other language follow the same meaning, information, message to the audience or readers. Logically, through translation process might consist of different changes in the text like; changes of the order of sentence's elements, the addition of other elements or their lost because it is almost impossible to find two languages that are equally in; syntax premises, morphology, semantic, pragmatic premises, etc.

A successful translation or coherent one sometimes is hard to be realized because of the differences that languages share among each other. Albanian and English language share more differences than similar ties because of their differences in grammar and in other premises. With such differences in languages' construction translation sometimes is done via different 
changes in word or sentence level in order to make a well transformation of meaning or message from source language to target language.

When it comes to text translation, translators always have to bear in mind the text analysis which deep down covers the studies of text linguistics. According to Vula (2019) text linguistics "is part of the study of linguistics which deals with the formation of the text, its construction, meaning, etc. Language is one of the basic elements of any country, and its history is equally important to be known in order to get deeply in other elements of text linguistics" (pg.38).

Whereas, according to Mujaj (2011:123) text linguistics is a science discipline of linguistics which researches the components of text structure, its relation, circumstances of its productions also its internal factors and external factors. In the middle of the 60s the case of the text was not developed and was not elaborated as later on" (found on Vula, 2019:39).

The focus of this paper does not elaborate generally in all aspects and divisions of text linguistics but only highlights one part of it which is: the internal part of the text.

According to Vula (2019), a text "is not just a group of sentences or words grouped together but there are rules for its internal organization. If we try to analyze deeply a text, we should pay attention to a lot of points or details that help a text to be well formed in order to comprehend it. A well-formed text in order to be communicative or informative one a text should follow several criteria, which were represented or showed by a lot of linguists as the constitutive principles of textuality. They can be ordered as follows: Cohesion, Coherence, Intentionality, Acceptability, Informatively, Situationality, and Intertextuality and three regulative principles of textual communication: efficiency, effectiveness, and appropriateness (De Beaugrande and Dressler 1981, Malmkjaer 1991, found on Vula, pg.42).

This paper will be focused only on the elaboration of: "Coherence" and "Cohesion" as two major principles of textuality.

\section{Cohesion and Coherence}

Cohesion is "the network of lexical, grammatical and other relations that provide links between various parts of a text. These relations or ties organize and, to some extent, create a text, for instance by requiring the reader to interpret words and expressions by reference to other words and expressions in the surrounding sentences and paragraphs" (Baker, 2018:194).

So, cohesion as one of the most important principles of text linguistics enables a translator to translate a source text by the addition of cohesive devices in order to make the translation meaningful as well as equivalent in a target language.

Cohesion is considered as a "surface relation" which links together "the actual words and expressions that we can see or hear" (Baker, pg.194).

According to Vula (2019) cohesion "is an important criteria and useful one for textuality which has to deal with the organization of the elements of a text. To make an organized text cohesion helps through phonetics, morphology, and syntactic. A well-formed text should consist with construction of the components in a text, an organization of grammar elements which helps text to be comprehensible and logic to"

The five main cohesive devices have been identified by Halliday and Hasan, such as: reference, substitution, ellipsis, conjunction and lexical cohesion. (found on Baker, 2018).

\section{Coherence}

Whereas, on the other hand, coherence as the second most significant criteria of textuality makes translation meaningful, comprehensible and enables the source text to be translated in the best way possible.

"Coherence as the second criteria of text linguistics is considered as a crucial linguistic element in producing a well-formed text. Coherence is what makes a text semantically meaningful. Coherence helps the ideas of texts to be logically related in the text in order to provide the readers the continuity of meaning of text sequences and a clear message" (Vula, 2018: 43).

Whereas, according to Baker (2018), coherence is" the network of relations that organize and create a text; coherence is the network of conceptual relations which underlie the surface text" (pg. 235). 
Generally, cohesion and coherence cannot function without each other since their collaboration enables the source text to be well translated to a target one. By using the cohesive devices translators transform the text in the most coherent way, especially when we deal with languages that share more differences rather than similarities in their construction.

\section{Research Methodology}

This research has been realized by using the empirical method. This research elaborates on the usage of cohesive devices which enables the coherence while translating from Albanian to English and vice versa. Except the coherent texts there will be presented also non-coherent text which will elaborate and specify the problems that translators might find during such translation.

The empirical research includes the analysis of two texts, which the first one is from Albania to English and the other one is from English to Albanian. Based on the text analysis, that has been made, there will be shown differences on: cohesive devices, linguistic relativism through translation and the issue of demonstrative pronouns and cases between English and Albanian languages.

\section{Hypothesis:}

The text translation from Albania to English will be via cohesive devices which it means will have a lot of changes in word addition as well as in changes of word classes.

The text translation from English to Albanian will be realized through the addition of cohesive devices as well as there will occur changes due to linguistic relativism and demonstrative pronouns as well as in noun's cases.

\section{Research question:}

What cohesive devices are used during translation from Albanian to English?

What changes are done in target text due to linguistic relativism, noun's cases and demonstrative pronouns, found on the English text?

\section{Coherent text}

\section{Albanian version: "E bija e mbretit}

Ish nje mbret, ish nje mbretereshe. Kishin nje vajze te vetme. Dhe vajza ishte e bukur dhe e menqur. Dhe aq e gezuar, sa qeshte dite per dite me shume here nga se kokrriza ka shega (...). Por nje dite, vdiq mbretersha dhe princeshes iu vrenjt pak buza. Nje nate, vdiq dhe mbreti dhe princeshes iu pre gazi. Dhe pak kohe me pare ra zjarri ne pallat dhe e dogji. Dhe princesha, e mbetur e varfer dhe e vetme, ndieu per te paren here trishtimin. Me zemer te fryer nga psheretimat, e bia e mbretit u vesh si fshatare, mori nje stap ne dore dhe doli nga dheu i t'et duke qare. Loti i pare qe derdhi, mbiu dhe menjehere doli nje rrenje trendafili, i gjate, i bukur, me dege shume e kudo qe derdhte lot princesha, mbinin trendafila. $\mathrm{E}$, ngaqe te qaret e saj s'kish pushim e te ecurit e saj s'kish qendrim, trendafilat mbinin ne te kater anet e botes. Nje dite, princesha, e lodhur dhe e trishtuar me teper se ditet e tjera, arriti ne qytet te Ispahanit, ne Persi. Atje qendroi ne nje gur dhe qau tri dite, e prandaj Ispahini eshte qytet ku jane trendafilat me te bukur te botes. Ne fund te dites se trete, princesha e mjere vdiq dhe trupi i saj u kthye dhe u be nje trendafil, deget e te cilit dolen me siper se gjithe te tjeret" (Faik Konica)

\section{Back translation: "Daughter of the king}

It was a king and a queen. They had a single daughter. And the girl was beautiful and smart. And she was so happy that laughed every day, more than a branch of granules of pomegranate. But one day, the queen died and the princess became sad and one night the king died and the princess stopped laughing. After a short time, there was a fire in the palace and burned him. And the princess was remained alone and poor for the first time she felt the sadness. With a swollen heart by sights, the daughter of the king wore as a peasant and took a bat in her hand and went out crying from her father's ground. The first tear, which she poured, sprang up immediately a beautiful long root rose, with many branches and whenever the princess poured tears, roses sprung up. Because of her persistent crying and her incessantly walking roses sprung up on the four sides of world. One day, the princess became more tired and sadder than the other days and finally arrived in city of Ispahan in Persia. She stayed there in a stone and cried for three days and therefore Ispahan is the city of the most 
beautiful roses in the world. At the end of the third day the poor princess died and her body turned into a rose, whose branches emerged all above others."

The text in Albanian language is written in narrative form. Narrative texts consist of descriptive sequences, explanations, informative, factual sequences and dialogs. They may include imaginary, factual, and fairy stories. According to Dibra \& Varfi (1999:106) a logic narrative it is conceived as sequential events related with elements, when events are presupposed by each other within a structure, which should be portrayed as out of time. These events are organized on coherence principles. A coherent text should have; an introduction part and defined conclusion, which it can be found on text presented below.

\section{Textual connectors}

Second element which makes this text coherent is the sequence connection through the use of connectors which help to relate the sequences of text and to make it more coherent.

For example:

"Dhe vajza ishte e bukur dhe e menqur..." (And the girl was beautiful and smart...)

To link the sequences of the text in order to be coherent we must use connectors which help the text to be meaningful. There are different types of connectors depended on their role in the sentence. In this sentence logically the connector "Dhe" (And) make a connection with the previous sentence and also adds new information about the description of the girl, which we can be classified as "logic connectives that express expanding relation of information, that express logic relation which links different contents of text" (Dibra and Varfi, 1999:92, same book)

"Por nje dite, vdiq mbretersha dhe princeshes iu vrenjt pak buza..." (But one day, the queen died and the princess became sad...)

In the second sentence the connector "Por" (But) it expresses an introduction to "new information" if we analyze the text before "Por" (But) there is a description of happy family while it came to this connector it leads to readers/hearers that something new happened and is not any good information. This type of connectors is seen as "logic connectives which express contravention relation". (Dibra and Varfi, 1999:93)

"E, ngaqe te qaret e saj s'kish pushim e te ecurit e saj s'kish qendrim, trendafilat mbinin ne te kater anet e botes..." (Because of her persistent crying and her incessantly walking roses sprung up on the four sides of world...)

In order to give the causality of "roses sprung up on the four sides of world "connectors which are presented above: "E, ngaqe" (Because of) help the sentence to explain the causality of "her persistent crying and her incessantly walking".

"Atje qendroi ne nje gur dhe qau tri dite, e prandaj Ispahini eshte qytet ku jane trendafilat me te bukur te botes..." (She stayed there in a stone and cried for three days and therefore Ispahan is the city of the most beautiful roses in the world...)

\section{In fourth example}

In making a coherent text additional information should be presented in the text in order to give clear information to readers/hearers. The presentation of "Ispahan" as "city of roses" in the text make sense to other sequences of the text correlating the fact that "her tears pours roses, and her journey ends in the city of roses" these correlations are made by the connector "e prandaj" (therefore) in giving reason of the representation of "Ispahan" city in the text.

\section{Articles}

When it comes to translation from Albanian language to English language at the first view it can be seen that the length of same texts is different. Why? It is already known that a text cannot be translated word by word or otherwise it might lose its meaning as a consequence of many differences among Albanian and English language.

Articles in English and Albanian language

E lodhur- tired

E bukur- beautiful 
E mjerè- poor

E menqur- smart

As it can be seen from the translation of adjectives taken from the text we can notice the difference of usage of articles in both languages. Since in Albanian language an article is considered "e" before the adjective in English language it cannot be placed in the same way. As it is known in English articles are divided into definite and definite articles; "a", "an", "the" and zero articles which are placed before the nouns or before adjectives which are followed by nouns. If we try to make the adjective in English preceded by an article without followed by a noun it is contradicted with English grammar rules, for e.g. "a pretty, a beautiful, a poor, and a smart" which make no sense without noun. English language in this case it requires the subject after a definite or non-definite articles.

"Një ditè, princesha, e lodhur dhe e trishtuar mè tepèr se ditët e tjera..." (One day the princess became more tired and sadder than the other days...)

As it can be noticed to make coherent translation it was necessary to add the verb "became" in order not to leave any word aside or otherwise it can lose the extra information (she feels worse than other days and we can make the inferences about anything new or the ending of the story) if the part "me teper se ditet e tjera" would not be included in translation would make less coherent text. The adding of the verb "became" realizes cohesion premises in order to make text coherent, without changing the class of words, so they still remain adjectives. The purpose of translation is not leaving anything aside or any left information, its function is to cover everything but in a coherent way.

\section{The Subject elements during translation}

Another element which is very interesting through translation from Albanian language and English language is the adding of subject. See, below:

"Ish nje mbret, ish nje mbretereshe. Kishin nje vajze te vetme..."

"It was a king and a queen. They had a single daughter..."

As it can be noticed in Albanian language a meaningful sentence can be realized without the subject and it starts with the past tense of the verb "to be" in this case "was". If we try to make the same formation of sentence in English language: "Was a king and a queen. Had a single daughter..." * which leads to meaningless sentence because English language requires indispensable subject in order to make coherent the text.

Example: Të dua (Albanian language)- it gives clear information, in which this "të" means "ty" (you), the reference it is consisted inside the sentence even that is not mentioned and for Albanian language it is this sentence is coherent.

I love you (English language)- The same expression in English language requires; a subject, verb and the direct object or the referent to whom is the subject (I) being expressed in this case to second person singular "You", which implies cohesion from translation of Albanian Language into English language, otherwise cannot be realized in any way.

Whereas in Albanian language the text can be coherent also if the sentence does not consist of a subject and the sentence is meaningful. With these examples (see translated text) it can be said that the coherence of text in Albanian language is implemented the cohesive devices which implement the coherence in English language during the translation process.

\section{Non coherent texts}

Non coherent texts produce texts which show no connection of text sequences, since above there was presented a text coherent which contain different elements which enable the coherence in text, whereas below will be presented a noncoherent text and its transformation during the translation from English language to Albanian Language.

\section{"A Train Journey"}

The people on the train were hot and tired. A tall young man sat next to three small children and their aunt. The aunt and the children talked. When the aunt spoke she always began with "Don't...'. When the children spoke they always began with "Why..." The young man said nothing. The small boy whistled loudly. "Don't do that, Cyril', said his aunt. Cyril stood 
up and looked out of window at the countryside. 'Why is that man taking those sheep out of that field?' he asked. 'Perhaps he's taking them to another field where there's more grass' said the aunt. 'But there's a lots of grass in that field. Why can't the sheep stay there?' 'Perhaps the grass in other field is better.' 'Why is it better?' The young man looked annoyed. 'Oh dear', thought the aunt, 'he' doesn't like children'. 'Sit down quietly, Cyril. Now, listen, I'm going to tell you all a story'... (Liz \& John Soars 2000)

"Udhëtimi në tren"

Njerèzit nè tren ishin kishin shumè vapè dhe ishin tè lodhur. Një njeri shtatgjatè nè moshè tè re ishte i ulur afèr tre fèmijève dhe hallès/tezèz së tyre. Halla/tezja dhe fèmijët po flisnin. Kur tezja/halla e tyre fliste ajo gjithmonë fillonte me "Mos" ...' Kur fèmijèt flisnin gjithmonè fillonin me "Pse..." Njeriu nè moshë tè re nuk thoshte asgjè. Djaloshi i vogèl pèshpëriste zèshèm. "Mos bëj ashtu, Cyril', i thoshte halla/tezja e tij. Cyril u ngrit dhe shiqoi fshatin nga dritarja. 'Pse ai njeri atje po i largon ato dele nga ajo fushë?' ai pyeti. 'Ndoshta ai po i dergon ato pèr nè ndonjè fushë tjeter ku ka mè shumè bar" tha tezja/halla e tij. 'Por nè atè fushë ka shumè bar'. Pse nuk i mban delet atje? 'Ndoshta bari nè fushèn tjetèr èshtè mè i mirè'. 'Pse èshtè mè i mirè?' Njeriu nè moshè tè re dukej i nervozuar. 'Oh i dashur', mendoi halla/tezja, 'ai' nuk i pëlqen fèmijët'. 'Ulu, Cyril. Tani, dègjo, Unè do t'iu tregojë tè gjithève një histori'... (translated by me)

This short story presented above has no coherence on the text. Firstly, the introduction part does not have a clear description of the situation on the train, as you can see it starts with the description of people on the train and then passes the attention of readers into other sequences of text. Furthermore, the body part of text starts with description "small boy" and passes the description of another scene "out of the train". As it can be seen textual connectors are also absent, and do not link the sequences of text.

For example:

"A tall young man sat next to the three children and their aunt. The aunt and the children talked". The description of the "young man" does not follow the description of other people in the train but it describes the situation of what they are doing. The second sentence it starts to introduce a dialog between an aunt and the children by the verb 'talked'.

"When the aunt spoke she always began with "Don't...' When the children spoke they always began with "Why..." The young man said nothing." Analyzing the description of dialog, it gives information of what always happens between 'the aunt' and 'the children'. Whereas the last sentence is non-coherent with previous one, not just by the absence of connectors but also it does not make sense to the description of dialog. On other hand, the conclusion part also is not clear enough, which does not full fill the message or the information of the story, and readers will be led with a lot of question marks on their mind.

\section{Linguistic relativism through translation}

Despite the fact that English and Albanian language pertain in the same Indo-European language family they show great differences which can be noticed during the translation process. One of them which usually Albanian students face during the learning of English language is the problem of translation of kinship.

For example: "The aunt and the children talked"- Tezja/Halla dhe fèmijèt po flisnin.

"My uncle is the best"- Daja/axha im èshtè mè i miri.

A great confusion is related to the "Linguistic Relativism", which has to deal with "examples of linguistic relativity across different languages and with differences of classification of experiences and that the lexical items of no two languages are perfectly matched" (Ljupco Stefanovski, English Lexicology, 2006:60). For example, English language has only one term for mother's sister and father's sister also for mother's brother and father's brother, whereas Albanian language has a separate term for these family's relation.

\section{The issue of demonstrative pronouns and noun's cases among English and Albanian languages.}

Demonstrative pronouns as category of pronouns are used to identify or point to a thing or things and people. In English language they are divided in two groups based on the distance (near or far) of things or people from the speaker and also according to plural or singular form; "This" is used for a thing/person which is near to the speaker in singular form, "That"- 
is used for a thing/person which is far from the speaker in singular form, whereas "These"-is used for things/people which are near to the speaker in plural form and "Those" is used for things/people which are far from the speaker. In Albanian language the same division is done according on the distance of objects/people in plural or singular form, also the division of demonstrative pronouns is done based on the gender of the objects or people such as: " $K y$ "- is used for a thing/person in singular form for males, "Kjo"- is used for a thing/person in singular form for females, whereas the demonstrative pronoun "Ai" it is used for a thing/person which is far from the speaker for male gender, "Ajo" - it is used for a thing/person which is far from the speaker for female gender. The same division for things/people it is done based on the gender which are far or near from the speaker; "Këta" - is used for things/people for male gender, which/who are near from the speaker, "Këto"is used for things/people for female gender, which/who are near from the speaker. Whereas "Ata" is used for male gender for things/people which/who are far from the speaker, and "Ato" is used for female gender for things/people which/who are far from the speaker.

For example: "Why is that man taking those sheep out of that field"?

"Pse ai njeri po i largon ato dele nga ajo fushë"?

As it can be seen during the translation from English to Albanian language or vice versa demonstrative pronouns change because English language does not make a distinction of demonstrative pronouns based on the gender. "That" while it is translated into Albanian language it is "Ai"- "He" which in English language it pertains in Personal Pronouns as third person singular used for male gender. The same thing it happens to "those sheep" - "Ato dele" in which" Ato" it is "They" in English language, also in "that field" which the demonstrative pronoun "that" it is translated as "Ajo" which in English language it is the third person singular "She".

If we try to replace demonstrative pronouns "That" with "He", and so on in this sentence it makes no sense and it is contradicted with grammar rules of English language;

"Why is he man taking they sheep out of she fields" *

Since we have the noun "Man" in the sentence we cannot use the personal pronoun "He" for the same referent, since the role of pronouns is to replace the same noun. Hence, translating demonstrative pronouns from English into Albanian language it leads to personal pronouns in sentences which the same are used for demonstrative pronouns.

Another distinction between English and Albanian languages in the field of pronouns is the absences of the difference in gender at third personal pronoun in plural form "They" in English language, whereas Albanian language it makes the gender distinction, see examples below;

1. Look, those girls over there. They are my friends- Shiqo ato vajzat atje. Ato janè shoqet e mia.

2. Look, those boys over there. They are my friends- Shiqo ata djemte atje. Ata janè shokèt e mi.

English language uses the personal pronoun "They" for both genders (males and females) whereas in Albanian language we have the third person plural for females and males. This absence in English language makes confusion to the beginners or elementary English learners especially from Albanian people. The only solution in order to translate from English to Albanian language the sentence or the text in more coherent way is to read carefully previous sentences which may tell you if the situation has to deal with male or female genders, otherwise the meaning can be lost.

Noun's cases among English and Albanian language

"Perhaps he's taking them to another field where there's more grass" - "Ndoshta ai po i dèrgon ato nè një tjetèr fushè ku bari èshtè mè i mirè".

According to the English grammar the pronoun "Them" it pertains in the group of objective pronoun depended from the cases which it has. Whereas the translation of this pronoun in Albanian language it is "Ato" as plural third personal pronoun in nominative case and in another case named "Rasa Kallzore" which English language does not have. Nouns and pronouns in English language are said to display noun case according to their function in the sentence; in addition, pronouns change the form when they change the case, whereas nouns do not change their form.

Nominative Case

Possessive Case

Objective Case 


$\begin{array}{lll}\text { Tiger } & \text { Tiger's } & \text { Tiger } \\ \text { They } & \text { Their, theirs } & \text { Them } \\ \text { Cases in English language } & & \end{array}$

Whereas in Albanian language it is contrary, pronouns and nouns change their form during the cases, in addition Albanian language consists of more cases which English language do not have.

$\begin{array}{lllll}\text { Rasa Emrore } & \text { Rasa Gjinore } & \text { Rasa Dhanore } & \text { Rasa Kallzore } & \text { Rasa Rrjedhore } \\ \text { Ato vajza } & \text { i atyre vajzave } & \text { Atyre vajzave } & \text { Ato, vajza } & \text { Atyre vajzave }\end{array}$

Cases in Albanian language

As we can see from the table in Albanian language if we talk for cases "as grammatical category we have to deal with certain forms of noun and their grammatical senses which they are expressed to. One of the forms which is in Albanian language is named "Lakimi" which can be described as the entirety of changes which noun undergoes, when it is used in different cases" (Akademia e shkenave e Shqiperise, Gramatika e Gjuhes Shqipe 1, 2002:111). The absence of this form of cases in English language it makes easily the translation from Albanian into English language, in other hand translation from English language to Albanian language it acquires more attention in these issues in gaining a coherent text. In Albanian language these changes are not found just in nouns during the cases, but also the forms of adjectives change based on the cases. In English language such changes are found neither in nouns nor in adjectives. While discussing changes which adjectives take, it cannot be forgotten to mention also that in Albanian language adjectives also have gender which lack in English language.

For example:

$$
\begin{aligned}
& \text { Albanian Language } \\
& \text { Luftëtar i ri (singular,male gender) } \\
& \text { Luftètare e re (singular, female gender) } \\
& \text { Luftëtarët e rinjè (plural, male gender) } \\
& \text { Luftètaret e reja (plural, female gender) }
\end{aligned}
$$

\author{
English Language \\ Young fighter (singular, for females and males gender) \\ Young fighter (singular, for females and males gender) \\ Young fighters (plural, for females and males gender) \\ Young fighters (plural, for females and males gender)
}

As it can be seen from above, adjectives in Albanian language form the gender and the plural form of adjectives by changing the consonants whereas in English language there is no distinction in gender as well as in plurality. Readers or hearers especially Albanian people should make inferences about any English text for what gender is being discussed in text since there are not grammatical rules that make such divisions. Whereas in Albanian language should be a distinction since if we translate an English text to Albanian language we should apply those grammatical rules in order to have a coherent translation, otherwise we cannot transmit the same meaning or idea and the translation would be meaningless to Albanian readers or hearers.

\section{Conclusion}

To sum up, it can be concluded that a coherent translation from English to Albanian or vice versa is realized via cohesive devices usage. The addition of cohesive devices such as: connectors or addition of subject make the translation meaningful and coherent in a target language. Based on the analysis, it can be stated that Albanian and English language differ mostly in gender distinctions, linguistic relativism and noun's cases. Such differences among these two languages cause many changes to happen during translation such as: addition of sentence elements, as well as omission of words, in order to make translation coherent and meaningful. Generally, translation requires a great background knowledge of source and target language's grammar in order to make adjustments without losing the message of a source language to target one.

\section{References}

[1] Akademia e Shkencave e Shqiperise. Instituti i gjuhesise dhe letersise (2002): Gramatika e Gjuhes Shqipe II. Tirane. 
[2] Akademia e Shkencave te R. se Shqiperise. Instituti i gjuhesise dhe letersise (2002): Gramatika e Gjuhes Shqipe I. Tirane

[3] Beci, B (2004): Gjuha Shqipe8: Gramatike; Drejtshkrim; Gjuha e folur dhe e shkruar. Shtepia botuese Dukagjini-Peje.

[4] Beci, B. (2004): Gjuha Shqipe7: Gramatike; Drejtshkrim; Gjuha e folur dhe e shkruar. Shtepia botuese Dukagjini-Peje.

[5] Beci, B. (2004): Gjuha Shqipe9: Gramatike; Drejtshkrim;Gjuha e folur dhe e shkruar. Shtepia botuese Dukagjini-Peje.

[6] Dibra, K. \& Varfi, N. (1999): Gjuhesi Teksti, Tirane: shblu.

[7] Halliday, M \& Hasan, R. (1976): Cohesion in English. London: Longman

[8] Liz \& John Soars. (2000): New headway- Elementary Student's book. Oxford New York: Oxford University Press.

[9] Mujaj, H. (2011): Semiotika dhe zhvillimi I saj. Prishtine: Faik Konica.

[10] Munday, J. (2016). Introducing Translation Studies. Fourth edition published by Routledge 2 Park Square, Milton Park, Abingdon, Oxon OX14 4RN.

[11] Saeed, J. I. (1997): Semantics. Malden, USA: Blackwell Publishing

[12] Vula. E. (2019). Theoretical research on the history of text linguistics. Academic Journal of Business, Administration, Law and Social Sciences IIPCCL Publishing, Graz-Austria. Vol. 5 No., ISSN 2410-3918. Retrieved from http://iipccl.org/wp-content/uploads/2019/03/38-45.pdf 